\title{
Protective Security in Australia: Scandal, Media Images and Reform
}

\author{
TIM PRENZLER \\ Australian Research Council Centre of Excellence in Policing \\ and Security \\ RICK SARRE \\ School of Commerce, University of South Australia
}

\begin{abstract}
This paper examines recent events and issues involving security providers that have drawn adverse attention in Australia, primarily through media reporting. The study covers the decade from 1999 to mid-2008. Eleven key events are examined, including fatalities resulting from security officer actions, illicit activity by motorcycle gangs involved in nightclub security, fraud in contracts for patrol services, and lax security at airports. The paper analyses how these events illustrate risk areas of security work and the limitations of the regulatory systems operating at the time. Recognition of the problems drove a 'second wave' of regulatory reform of the industry in the direction of comprehensive licensing, with enhanced training requirements, tougher entry and licence retention tests, and closer scrutiny of security providers - consistent with an emerging best practice model of industry regulation. The authors support the general direction of these innovations while emphasising the need for proactive monitoring of the industry and a nationally consistent system of licensing.
\end{abstract}

\section{Background: Growing pains}

The growth of the security industry is considered one of the key features of the evolution of the policing complex since the end of World War II. In a recent global review of crime and security, Jan van Dijk (2008, p. 15) estimated that, in very approximate terms, "Worldwide, more people are employed as a private security officer $(348$ per 100,000$)$ than as a police officer $(318$ per 100,000)." It is, in fact, difficult to measure accurately the size of both public and private security and make fair comparisons against the common benchmark of sworn police. On available data, police to private security ratios vary enormously, with apparently larger reliance on private security providers in countries such as the United States and South Africa, 


\section{TIM PRENZLER AND RICK SARRE}

and less reliance upon private security personnel in European countries (van Steden $\&$ Sarre, 2007).

A recent Australian study found there were no precise figures for the number of people working in private security (Sarre \& Prenzler, 2005[2009]). According to the 2006 Australian Bureau of Statistics (ABS) census, the total number of persons involved directly in private and public security work as their main occupation was 52,768, compared to 44,898 police. The cross-over in numbers occurred around 1998. In the decade from 1996 to 2006, the number of security providers increased by 41 percent, the number of police increased by 14 percent and the population increased by just under 12 percent. The 2006 census figures translate into rates of 226 police and 266 security providers per 100,000 - much lower than van Dijk's estimated global averages for both groups. The Australian census data count includes debt collectors, bailiffs and security advisors. A count of groups more closely associated with traditional policing tasks - private investigators, insurance investigators, armoured car escorts, security officers, alarm, security and surveillance monitors, and crowd controllers - makes for a total of 38,275 . This number is almost 7,000 less than the 44,898 police. However, the census figures only record a person's 'main occupation' and the part-time members of the security workforce are numerous. Indeed, licensing figures indicate a very large part-time work force, with approximately 92,500 licences held by individuals across Australia in 2007.

The most recent financial data for the Australian security industry (for 2005-06) show that the private security sector paid salaries and wages of $\$ 1.5$ billion and had a gross income of $\$ 4.4$ billion, which was 0.2 percent of all industry income reported by the Australian Bureau of Statistics. At the end of the financial year 2006/07 there were 5,523 registered businesses in security. There was a large number of small companies, with 45 percent being sole operator companies. At the same time, about 45 percent of the market was dominated by five large firms (Sarre \& Prenzler, 2005[2009]).

A wide variety of influences has been associated with the growth of private and public protective security services. Specific government policies of privatisation have generally not been extended to policing at any significant level. Instead, market demand has been driven by the often dramatically rising crime rates from the 1970s to the 1990s, followed by a sustained cultural re-orientation towards selfprovision of security (van Dijk, 2008). The wide gap in labour costs between police and security has been another factor, along with insurance and workplace safety requirements, improved security technology and the post-9/11 counter-terrorism agenda. International research shows that premises with security have significantly lower rates of criminal victimisation than those without (van Dijk, 2008, p. 129ff).

In Australia, each state and territory has developed a licensing system for security providers that resulted from a major shift, mainly in the 1990s, from partial and minimalist forms of occupational registration to full licence requirements. This 'first wave' of reform coincided with an upsurge in security personnel and entailed compulsory pre-entry training and a set of disqualifying criminal offences for licences. The main occupational groups targeted by these changes were private contract security firms, guards, crowd controllers and private investigators. The introduction 
of licensing was driven by a series of scandals across the 1980s and early-1990s (Prenzler \& Sarre, 1999). These scandals included, primarily,

- a large scale, long-term, problem of assaults and negligence by crowd controllers,

- recurring allegations of incompetence and poor training,

- convicted criminals accessing security skills courses,

- fraud in alarm and patrol services by major firms,

- trade in confidential information between private investigators and public servants,

- corrupt preferential arrangements between police and emergency security services,

- misuse of firearms in public places,

- suspected insider thefts by security officers,

- enormous waste of police resources responding to false intruder alarms, and

- misleading and deceptive advertising of security products.

The general direction of the new licensing systems received widespread support from industry members (Prenzler \& Hayes, 1999; Prenzler \& Sarre, 1999), although there was little done to evaluate the impact of the changes. Limited evidence regarding licence application rejections, for example, showed that potentially inappropriate persons were being excluded from the sector. Nonetheless, a number of issues remained. One was that there was no national consistency, with a patchwork of standards and terminology across the eight jurisdictions. In addition, while New South Wales, South Australia and Western Australia eventually developed comprehensive, or near-comprehensive, licensing regimes, other jurisdictions left out important areas of security work, such as in-house guarding, station monitoring and lock-smithing. There were also concerns about the extent to which criminal history checks were properly 'national', and concerns persisted about pre-entry training standards which were highly variable but limited to five days on average in most jurisdictions. There was also little in the way of proactive auditing of conduct once licences were issued.

\section{Recent adverse events}

By the year 2000 it appeared as though the regulatory regime rolled out over the 1990s had largely taken effect as intended. Despite the concerns outlined above, scandals involving security providers were much less prominent in the media. The culmination of these developments was the successful showcase of the publicprivate partnership in security at the 2000 Sydney Olympics (Sarre \& Prenzler, 2005, p. 195). Within a few years, however, a build up of fresh scandals forced regulators to re-think their systems. These events are analysed below using a range of sources, primarily media reports. The focus in this paper is on these public scandals and their 
implications for appropriate control of the industry. The reforms they provoked are still in their early stages of implementation and are the subject of a separate, more detailed, evaluation over the longer term by the authors. The remaining section of the paper therefore includes only some brief observations about the likely success of the new systems.

\section{THE BRINKS ARMED ROBBERY}

Australia's largest armed robbery was carried out against a Brinks armoured van in a Brisbane suburb in 1999. The robbers made off with $\$ 2.2$ million dollars. Suspicions immediately focused on Matthew Kelly, the security guard driving the van. He had previously been investigated over ATM thefts in New South Wales, and one week after starting with Brinks $\$ 80,000$ went missing from a van in which he was a crew member. In regard to the Brisbane robbery he allegedly was accosted by masked gunmen as he waited in the vehicle while the other guards were inside a shopping centre. He stated he feared for his life, opened the van to the robbers and drove it to a nearby location where it was unloaded.

There was some contention that, when accosted, Kelly should have followed a 'drive away' policy or dropped down inside the bullet proof vehicle and used the radio and duress button. He was also unarmed because he did not have a weapons licence. Kelly disappeared in 2000. In 2004 two alleged accomplices in the robbery were charged with his murder, in the absence of a body. The men were acquitted, but, during the trial, a friend of Kelly's claimed he refused an invitation by Kelly to help with the robbery. He also stated that the security guard later told him he was involved in the robbery. Kelly had also made enquiries related to creating a false identity and finding a country without an extradition treaty with Australia (Dibben, 2000, 2004; Kellett, 2007).

\section{THE DEATH OF DAVID HOOKES}

In January 2004 well-known cricketer David Hookes died following a physical altercation with a crowd controller, Zdravco Micevic, who was undertaking order maintenance duties at a hotel in Melbourne. The case received enormous media coverage which included negative insinuations about the behaviour of Micevic and his colleagues. There was conflicting testimony concerning provocation and attacks by both Micevic and Hookes. Whatever the actual sequence of events, the circumstances of the altercation, taken in their entirety, suggested inappropriate conduct by the security officers. In particular, security staff followed Hookes' party after they had been ejected from the hotel. In a second altercation, on a footpath at some distance from the hotel, Micevic struck Hookes in the head and Hookes fell to the ground, fatally hitting his head on the road. The accused, who was already facing assault charges over a previous incident, was charged with manslaughter, but the jury at his trial accepted that he had acted in self-defence and he was acquitted (Madden, 2005). 


\section{THE SYDNEY ARMED ROBBERY SHOOTING}

Six months after the David Hookes incident, in July 2004, a Sydney plainclothes cash-in-transit guard, Karen Brown, shot dead William Aquilina who had been observed stealing a bag containing approximately $\$ 55,000$. Aquilina had viciously assaulted Brown with a knuckleduster but was fleeing the scene when he was shot. Brown was charged with murder but she was later acquitted by a jury who accepted that she had fallen into a state of 'post-traumatic automatism' and believed she was acting in self-defence (Wallace, 2006). The shooting set off criticisms of inadequate regulation of subcontracting in the 'soft skin' cash-in-transit industry, in which solo plainclothes security officers transport cash without armoured vehicles. The Transport Workers Union alleged that many operators were highly exposed to robbery and injury, and were carrying cash well above the set limits (O'Rourke, 2004).

\section{THEFT OF FIREARMS FROM SECURITY FIRMS}

A scandal built in New South Wales across 2003-4 after numerous firearms were stolen from security officers and from the premises of security firms. The thefts called into question the adequacy of security for weapons, especially those stored by security firms. In a three month period in 2003, 56 firearms were stolen in six separate incidents. The thefts included 31 Glock pistols stolen from a firm aptly named Obliging Security. In another incident, security officers were robbed of three semi-automatic pistols and a large sum of cash while servicing an ATM (Duff, 2005; Vermeer, 2004).

\section{INFILTRATION OF CRIMINAL MOTORCYCLE GANGS INTO ADELAIDE NIGHTCLUB SECURITY}

In Adelaide in 2003-4 a scandal developed over the alleged infiltration of nightclub security by bikie gangs involved in the sale of illicit drugs, money laundering and gang fights. Concerns were fuelled by escalating violence between gangs as the Hell's Angels and Finks squared off in a turf war, with shows of strength, drive-by shootings and brawls. In one incident after midnight on a Friday night "a busload of up to 50 Finks motorcycle club members bombarded venues, assaulting staff and refusing to pay for drinks" (Merola, 2004, p. 1). It was reported that police believed "up to 80 percent of licensed premises in Adelaide's CBD that employ security firms were using companies with links to outlaw motorcycle gangs" and that "more than 60 licensed premises around the state use those companies" (Kelton, 2003, p. 1; also OCBA, 2004).

\section{PRISONER ESCAPES IN PERTH}

In Perth in 2004 seven prisoners escaped from court custody while under the control of a private security contractor. The prisoners overpowered three unarmed security guards at the Supreme Court, stole a key which allowed them to exit the 
building and then carjacked two vehicles from members of the public outside the court building (Pennells, 2004). The incident put a question mark over cost-cutting in court security and the privatisation of prisoner security. All the men who escaped were classified as 'dangerous' and had long criminal histories. The escape caused public alarm and triggered a massive manhunt by police across Perth's southern suburbs, including a high speed vehicle pursuit and the shut down of a freeway.

\section{VIOLENCE AROUND LICENSED PREMISES}

The high-profile death of David Hookes was only the tip of the iceberg of violence associated with security providers at licensed premises. In January 2004 the Adelaide Advertiser reported that police had charged 87 bouncers for assault offences in the previous two years (Hunt, 2004). It was estimated in early 2004 that more than 50 people in Victoria were suing security providers seeking compensation. The injury list included broken jaws, fractured skulls and severe bruising (Butler \& Kelly, 2004; Owen-Brown, 2004). The problem was not exclusive to licensed premises. In a high profile case in Adelaide five brothers sued security staff after allegedly being bashed in Westfield Ltd's Marion shopping complex (The Advertiser, 2004a).

Indications were that many of the problems related to the same security staff and venues. A report by the South Australian Office of Consumer and Business Affairs cited police views and observations that crowd controllers contributed to a majority of the violence. The report noted that:

SAPol has surveillance tapes showing extreme acts of violence by crowd controllers including vicious attacks on women and running street bashings. Assault data shows that high proportions of the alleged assaults involve blows and kicks to the head region often requiring surgery (OCBA, 2004, p. 5).

The issue focused attention on the training and supervision of crowd controllers. It was revealed that in many cases the licence requirements could include as little as three hours training in the physical component of crowd control. It was also alleged that people were obtaining licences even though they could not speak English (Nankervis \& Merola, 2004). Concerns were also expressed that inadequate training and staffing meant that many crowd controllers were themselves over-exposed to injury and abuse. In South Australia, the Australian Hoteliers Association called for a national training standard that emphasised 'verbal skills and customer service', while the Liquor, Hospitality and Miscellaneous Workers Union also called for greater attention to 'employer responsibility (and) responsible service of alcohol' (The Advertiser, 2004b, p. 26).

\section{CHUBB AGAIN}

In October 2004 Australia's largest security firm, Chubb, pleaded guilty in the Federal Court to 26 charges, brought by the Australian Competition and Consumer Commission, that it had misrepresented its ability to fulfil conditions in its mobile patrol contracts (Goodsir, 2004). The relevant contracts were in Sydney, the Central 
Coast, Canberra and Tasmania. Chubb faced losing its licence and a maximum penalty of $\$ 5.8$ million for breaches of the Trade Practices Act. After pleading guilty, the company was fined $\$ 1.5$ million. The reduced penalty was for 'lack of intention, the guilty plea, cooperation and rehabilitation'. Chubb also 'dismissed senior management, implemented new electronic verification systems, brought back some franchises, paid rebates to clients and implemented a major culture change' (Wallace, 2004, p. 1).

\section{AIRPORT SECURITY}

In mid-2005 the federal government launched a major review of airport security by a UK security expert following revelations of drug smuggling involving baggage handlers and of lax physical security and theft of goods. A major trigger factor was the conviction in Bali of Australian Schapelle Corby for trafficking marijuana. Corby was arrested in October 2004 after flying to Bali from Brisbane via Sydney. Her defence alleged that the drugs found in her baggage at Bali airport were placed there by Australian airport baggage handlers as part of an interstate trafficking operation (Wheeler, 2005). The Indonesian court rejected her arguments and she was imprisoned for a period of twenty years.

An Independent Review of Airport Security and Policing for the Government of Australia by Sir John Wheeler (2005) identified serious inadequacies in security that made regional and capital city airports highly vulnerable to theft, terrorism, trafficking in illicit goods and infiltration by organised crime. Wheeler described a complex set of problems, including inadequate screening and supervision of personnel in security and baggage handling; lack of entry and exit control at key points, especially at cargo and 'airside' areas; insufficient cargo screening, especially for explosives; and limited threat assessments. Airport policing was described as 'often inadequate and dysfunctional'; with rivalries, lack of coordination of policing agencies and lack of information sharing (including between public and private sectors). A key message, hidden somewhat behind Wheeler's polite language, was that the travelling public was grossly over-exposed to terrorist attacks (Wheeler, 2005, p. xi; Franklin, 2005).

\section{SYDNEY TRANSIT POLICE}

In 2005 a series of problems with Sydney's 600 transit police was brought to light. In an initial incident, two men wearing balaclavas stole a key from the driver of an empty Cityrail train. The key allowed access to all trains in the metropolitan area. Keys were also stolen in a subsequent incident (Sydney Morning Herald, 2005). In a period of heightened concerns about terrorism, the thefts revealed basic flaws in the rail security system. The problem was compounded by claims that transit police were heavy handed and making unlawful arrests, and that there was a high volume of complaints against officers. An Ombudsman's inquiry indicated officers were exceeding their powers and were often too quick to make arrests and use force. It also found that the quality of complaints investigations was extremely poor (Kennedy, 2005, p. 1; Ombudsman, 2005, pp. 69-72). 


\section{INFILTRATION OF SECURITY SERVICES BY CRIMINAL GANGS}

In 2007 the Australian Crime Commission (ACC) launched an investigation into possible infiltration of the security industry by organised crime. The investigation was sparked by evidence of links between the two groups from other ACC investigations. The 2007-8 federal budget included $\$ 8.7$ million over two years for the investigation. The Commission took the unprecedented step of advertising widely for persons to come forward with information (ACC, 2008; A-GD, 2007).

\section{MISCELLANEOUS}

The security industry was also subject to bad press in other areas. The highly publicised death of Brisbane woman Dianne Brimble from a drug overdose on a cruise ship in September 2002 led to allegations that security staff on the ship were told to ignore drug use and assaults and that bar staff were paid bonuses to sell more alcohol (McIlveen, 2006). In 2005 allegations were made that guards at Parliament House in Canberra - 'Australia's no. 1 terrorist target' - were not properly vetted, were poorly paid, suffered significant morale problems and were often pulled from their posts to act as crowd controllers at House events (McManus, 2005). In 2006 a judge made highly critical comments about security at the Australian Royal Mint after sentencing an employee convicted of stealing $\$ 135,000$ in coins over a 10 month period. The theft necessitated a full review of security at the Mint by the Australian Federal Police (Campbell, 2006). In Melbourne in 2006 a Westfield Shopping Centre representative issued an apology after a security officer refused to allow two disabled men to take borrowed centre wheelchairs to their car. As a result one man was carried by his sister and the other crawled five metres to the car (Silkstone, 2006). Finally, reports on border security revealed significant gaps in surveillance and screening. For example, audits indicated that 31 percent of prohibited items passed through mail centres undetected and 21 percent of prohibited items passed through airports (ANAO, 2005, pp. 28, 17; Parnell, 2008).

\section{The regulatory response}

At the same time that these scandals were developing across Australia there was a growing convergence of opinion about optimal regulation of protective security. The convergence, international in scope, included industry professional associations, regulators, government policy units and academics. The consensus position has been summed up in two recent papers by Button and George (2006) and Prenzler and Sarre (2008). The 'smart regulation' model advocates comprehensive licensing of security tasks, compulsory training that ensures beginning competencies, national criminal history checks for disqualifying offences, a robust complaints and adjudication system, and proactive monitoring of the conduct of security firms and operatives.

In Australia, the need for smart regulation of the security industry was brought home by the scandals described above and the associated failure of the existing 
regulatory system to prevent their occurrence. While some of the cases appeared to be 'new', others were merely a continuation of problems going back at least as far as the 1980s and 1990s, including violence, insider crime, and fraud in contracting. In the Chubb case, it was the third time the company had been charged by the ACCC in 10 years (Goodsir, 2004). Media exposure underscored the need for a better system for ensuring public confidence. Confidence levels are not likely to be maintained in a regulatory environment replete with stories of major security failures - such as breaches of airport security - or frequent security failures affecting ordinary citizens - especially in assaults and deaths associated with the mismanagement of licensed premises. The failed criminal cases also highlighted the inadequacy of criminal law as a mechanism of redress. The incidents of the last decade especially highlighted the need for better screening and management of security operatives and better training in areas such as firearms, physical restraint and conflict de-escalation. The scandals also demonstrated how the regulatory system was overly passive in relying on the screening of individuals, through the licence application and renewal process, as a mechanism to underwrite good conduct. Much more proactive monitoring of security officer behaviour, consistent with the smart regulation model, was needed to reign in abuses.

As noted, the scandals provoked extensive negative media reports on the security industry, with phrases such as 'Wild West security guard culture' (Knowles, 2004), 'airport security fiasco' (Dodson \& Wilkinson, 2005), 'security farce'(Dunn \& Buttler, 2006) and 'border security system "failing"' (Parnell, 2008). The scandals peaked in the 2004-5 period when Victoria, South Australia, New South Wales, Queensland and Western Australia launched reviews of their regulatory systems, which followed amendments to regulations in 2003-4 in the Australian Capital Territory, Tasmania and the Northern Territory. The following section briefly outlines the main changes to licensing systems that occurred over a period of several years and which are now nearing their conclusion.

In all Australians jurisdictions, the general direction of change was towards licensing of a wider range of security tasks and security practitioners, including locksmiths, consultants, in-house security personnel, trainers, and electronic system installers and monitors (ASIAL, 2005; OCBA, 2004; OFT, 2006; The CIE, 2007). There was also an enlargement of disqualifying offences to cover areas such as firearms offences, drug offences and criminal activity generally, as well as automatic suspensions of licences when licence holders were charged with an offence. Some jurisdictions, such as South Australia and Victoria, introduced checks on an applicant's 'close associates'. The South Australian parliament went one step further and passed the Serious and Organised Crime Control Act 2008 designed, in part, to break the nexus between bikie gangs and crime, with an eye on the links between some gangs and the security guarding industry. By virtue of section 35 of the Act, having a 'close associate' who is a member of a 'controlled' organisation (and who is not familial) and meeting them on six occasions within a 12 month period is now an offence carrying a term of imprisonment of five years. 


\section{TIM PRENZLER AND RICK SARRE}

Regulatory agencies were also given greater powers to deny or suspend licences on discretionary grounds, including evidence of poor character (using a national police intelligence check) or inappropriate behaviour, such as using confidential intelligence. There were also large numbers of minor changes aimed at keeping the licensing system up-to-date and improving the accountability of licence holders. These covered diverse matters such as display of ID; keeping of records and recording incidents; and advising the regulator of changes in circumstances, including if the licence-holder has been charged with an offence. There were also associated changes in liquor licence regulations in some jurisdictions - focused on stipulated ratios of crowd controllers to patrons, and powers to shut down premises which display repeat problems of violence.

South Australia, in a further attempt to break or weaken the nexus between violence, security guarding and organised crime, introduced several radical innovations, including random drug and alcohol testing of crowd controllers (including steroid tests), fingerprinting of applicants, and a discretionary power to order applicants or licence holders to undertake a psychological test (OCBA, 2004). In New South Wales the legislative amendments included a strong focus on safe storage of firearms, upgraded inspections of storage facilities and of weapons licence holders, a reduction in the calibre of allowable firearms, and enhanced firearms training. A requirement for stronger justifications for weapons was also expected to reduce the number of firearms carried by security officers (Saleh, 2003).

One major step forward was in the area of training, where jurisdictions agreed to adopt nationally accredited certificate level courses for entry into operative level security work. This provided security staff with a basic qualification and some consistency in the curriculum. The new curricula appear to place more emphasis on communication, conflict management, management of intoxicated persons, and legal and procedural requirements. Moreover, a greater focus was placed upon specialist aspects of different licences. Preliminary research by the authors suggests that the changes increased training times on average from 3-5 days to 10-12 days. South Australia was a major exception, with the introduction of a two month pre-licence training program.

Of particular on-going concern in the training area, however, is that there is little evidence of the use of formal training needs assessments to determine the ideal curriculum content, methods of instruction and assessment, and optimal training periods. In addition, training requirements are restricted to individual 'operatives', with no requirements for the holder of a company licence or government security managers to have any training, including in key areas such as risk assessments or security procedures.

Another major unresolved issue is that of national consistency. Significant differences remain between jurisdictions, including different licence categories and terminology. There are major differences in areas such as fingerprinting, drug and alcohol tests, probationary (on-the-job) training requirements, disqualifying offences and disqualifying periods. These all create inconsistencies in standards and bureaucratic obstacles to inter-jurisdictional portability of licences. There are also 
differences in the role of stakeholders on regulator advisory boards, and the use of enforceable codes of conduct. There is also no agreement in Australia on mandatory membership of firms in professional associations and a 'co-regulatory' role for these associations, as advocated by the peak body the Australian Security Industry Association Limited (ASIAL) (OFT, 2006).

The degree of industry input was also a point of contention in the development of the new systems. While consultation was very open and systematic, even painstaking, in some jurisdictions - most notably Queensland; in other locations a good deal of the changes were simply presented as a fait accompli by government - most notably in New South Wales (OFT, 2006; ASIAL, 2005). As each jurisdiction introduced a review and change process, ASIAL took the opportunity to renew earlier efforts to have governments adopt its policy of comprehensive licensing and national consistency in licensing. In 2007 a move by COAG (Council of Australian Governments) to introduce 'harmonisation' (The CIE, 2007) was vetoed by the former New South Wales Premier Morris Iemma, allegedly because it would entail reducing standards in his state (Coorey, 2007). However, the July 2008 meeting made a commitment to 'a possible national system for security industry licensing by mid 2010' (COAG, 2008).

Following the Wheeler Review, referred to above, former Prime Minister John Howard announced an allocation of \$200 million in airport security restructuring and improvements. The plan included Australian Federal Police based control on-site at major airports, fingerprinting and other biometric screening for airport staff, training upgrades, enhanced sharing of information between agencies, additional screening of passengers and baggage, increased airside perimeter patrols, wider CCTV coverage, improved technologies for detecting explosives, and the creation of investigation teams at major airports to focus on organised crime (Customs, 2005; Dodson \& Wilkinson, 2005). In 2008, however, accusations surfaced that the full complement of airport police had not been reached and many of the security upgrades had only been partially implemented (O'Brien \& Wilson, 2008). In 2008 similar problems of inadequate checking of goods and vetting of staff at seaports were identified by Customs' Director of National Intelligence and Targeting in testimony before a parliamentary committee (Maley, 2008). There was also a question mark over whether a culture of neglect and 'cover ups' in security management had changed after airport security whistleblower Allan Kessing was convicted of a criminal offence over the leaking of adverse internal security reports that were part of the background to the Wheeler Review (Merritt, 2008).

The violence problem remains the main area where significant and lasting improvements are likely to be extremely difficult to achieve. In the cash-in-transit industry, an ongoing problem with armed robberies and killings of both guards and robbers indicates that security standards in the industry are still not adequate (Tibbitts, 2008; Ife, 2005; Lam, 2008). In crowd controlling, media reports of assaults and deaths have continued into 2008 (e.g., Healy \& Doneman, 2008). Violence associated with crowd controllers around licensed premises is the most significant problem in protective security and a particular point of concern relates to the absence 


\section{TIM PRENZLER AND RICK SARRE}

of any national monitoring of indicators. Nor are there any nationally coordinated assessments of the impact of the new controls.

\section{Conclusion}

This paper has highlighted the potential for security work to slide into a range of undesirable behaviours with adverse consequences, sometimes deadly, for the recipients of security actions. Recent scandals, prominently reported in the national media, combined with the continued growth of security, underscore the need for vigorous regulation of the industry to ensure the highest possible standards of conduct. New licensing conditions, including wider coverage of the industry, tougher screening tests and enlarged and expanded training requirements, are consistent with an emerging international model of best practice regulation. There is a prospect of improved conduct and a better image for the industry, although there are also question marks over several key areas. One concerns the training and supervision of security officers, especially crowd controllers. Major reform in these areas is essential if one were to address adequately the problem of violence in and around licensed premises that adversely colours the whole industry. Another question concerns the extent to which regulators are able to monitor the conduct of security providers independently of complaints or criminal charges.

Finally, there remains a question over the extent to which any new regulations will address the need for a more effective security culture and security management skills in key institutions and at key infrastructure locations. More generally, there needs to be a more explicit commitment by governments to performance measurement and evaluation of the impact of the regulatory reforms with a view to continuous improvement.

\section{References}

ACC. (2008). Private security industry special intelligence operation. Sydney: Australian Crime Commission. Retrieved September 29, from http://www. crimecommission.gov.au/html/pg_private_security_industry.html.

A-GD. (2007). Federal budget targets criminal infiltration of the domestic security industry. Media Release, 8 May. Canberra: Australian Government AttorneyGeneral's Department.

ANAO. (2005). Managing for quarantine effectiveness - Follow-up. Canberra: Australian National Audit Office.

ASIAL. (2005). Security industry position on Security Industry Amendment Bill 2005. Sydney: Australian Security Industry Association Limited.

Butler, M., \& Kelly, J. (2004, January 22). Victims suing bouncers. Herald Sun, p. 4. 
Button, M., \& George, B. (2006). Regulation of private security: Models for analysis. In M. Gill (Ed.). The handbook of security, (pp. 563-585). Houndmills, Hampshire: Palgrave Macmillan.

Campbell, R. (2006, June 22). Mint coins thief jailed for three years. Canberra Times, p. 3.

COAG. (2008). Communiqué. Sydney: Council of Australian Governments Meeting, 3 July.

Coorey, P. (2007, April 14). Premier muscles up to bouncers, without irony supplement. The Sydney Morning Herald, p. 6.

Customs (2005). Securing and policing Australia's airports - Statement from the Prime Minister. Retrieved September 29, from http://www.customs.gov.au/ site/page.cfm.

Dibben, K. (2000, February 27). \$3m stolen in a minute. Sunday Mail, p. 4.

Dibben, K. (2004, September 12). Friend tells court of offer to join brinks van robbery gang. Sunday Mail (Qld), p. 22.

Dodson, L., \& Wilkinson, M. (2005, September 23). Exposed: Airport security fiasco. Sydney Morning Herald, p. 1.

Duff, E. (2005, April 24). Calls to disarm guards as gun thefts rise. Sun Herald, p. 25.

Dunn, M., \& Buttler, M. (2006, August 21). Security farce: Criminals cleared to work at our airports. The Courier Mail, p. 1.

Franklin, M. (2005, September 24). PM should be blushing. The Courier Mail, p. 33.

Goodsir, D. (2004, November 1). Chubb to face loss of licence over rorts. Sydney Morning Herald, p. 3.

Healy, H., \& Doneman, P. (2008, September 7). Deadly nights out - Every two months, one person never makes it home. Sunday Mail, p. 35.

Hunt, N. (2004, January 22). Death of a champion, two years - And 87 bouncers charged. The Advertiser, p. 4.

Ife, H. (2005, September 21). Security shake-up on cards. Herald-Sun, p. 27.

Kellett, C. (2007, October 17). QLD's biggest cash heist accused in court. Brisbane Times. Retrieved September 28, from http://www.brisbanetimes.com.au/ news/.

Kelton, G. (2003, October 18). Bikie gangs linked to 60 liquor venues. The Advertiser, p. 9.

Kennedy, L. (2005, October 15). Transit police powerless: Union. Sydney Morning Herald, p. 7.

Knowles, D. (2004, August 1). Revealed: Queensland's gun toting security industry. Sunday Mail (Qld), p. 3. 
Lam, M. (2008, March 30). Blitz on robbers - Crime squad mop up armed gangs. Sunday Telegraph, p. 32.

Maley, P. (2008, September 30). Lax screening of dock workers 'a crime risk'. The Australian, p. 1.

McIlveen, L. (2006, July 4). Cruise guards 'ignore drugs'. The Courier Mail, p. 3.

McManus, G. (2005, July 26). Top guards never vetted. Herald-Sun, p. 4.

Merola, A. (2004, January 11). Bikie warning at nightclubs. Sunday Mail (SA), p. 8.

Merritt, C. (2008, April 25). Pardon this whistleblower, say the law's big names. The Australian, p. 29.

Nankervis, D. \& Merola, A. (2004, January 25). David Hookes 1955-2004: New pressure on bruised industry. Sunday Mail, p. 5.

O'Brien, N., \& Wilson, P. (2008, May 2). Airports left with very thin blue line. The Australian, p. 3.

O’Rourke, J., \& Kidman, J. (2004, July 4). Missing: 163 handcuffs, 203 batons ... and staff morale. Sun Herald, p. 9.

O'Rourke, J. (2004, August 15). Attacked guard accused of carrying excess cash. The Sun Herald, p. 13.

OCBA. (2004). Statutes Amendment (Liquor, Gambling and Security Industries) Bill 2004. Adelaide: Government of South Australia, Office of Consumer and Business Affairs.

OFT. (2006). Draft Security Providers Act 1993 public benefit test. Brisbane: Office of Fair Trading.

Ombudsman. (2005). Annual report 2004-5. Sydney: New South Wales Ombudsman.

Owen-Brown, M. (2004, February 17). Heaven guards accused of assault 80 times in a year. The Advertiser, p. 4.

Parnell, S. (2008, January 19-20). Border security system 'failing'. The Weekend Australian, p. 5.

Pennells, S. (2004, July 23). Sorry they got away, says AIMS. West Australian, p. 4.

Prenzler, T., \& Hayes, H. (1999). An evaluation of the Queensland Security Providers Act. Australian and New Zealand Journal of Criminology, 32(1), pp. 79-94.

Prenzler, T., \& Sarre, R. (1999). A survey of security legislation and regulatory strategies in Australia. Security Journal, 11(2), pp. 7-17.

Prenzler, T., \& Sarre, R. (2008). Developing a risk profile and model regulatory system for the security industry. Security Journal, in press.

Saleh, L. (2003, November 2). Handgun crackdown - Security firms face tougher weapons tests. Daily Telegraph, p. 4.

Sarre, R., \& Prenzler, T. (2005). The law of private security in Australia. Sydney: Thomson LBC. 
Silkstone, D. (2006, January 19). Mall's wheelchair rule humiliates men. The Age, p. 3.

Sydney Morning Herald (2005). Two sets of keys to Sydney's trains stolen. Retrieved October 24, from http://smh.com.au.

The Advertiser (2004a, August 30). Bashed brothers launch civil lawsuit, p. 3.

The Advertiser (2004b, April 16). More talk, less action for bouncers, p. 26.

The CIE. (2007). Harmonisation of private security industry regulation. Canberra: Centre for International Economics, Report to the Federal Attorney-General's Department.

Tibbitts, A. (2008, August 20) Robber dies in bungled raid. The Sydney Morning Herald, p. 7.

van Dijk, J. (2008). The World of Crime. Los Angeles: SAGE.

van Steden, R., \& Sarre, R. (2007). The growth of private security: Trends in the European Union. Security Journal, 20(4), pp. 222-235.

Vermeer, T. (2004, August 15). Guards give up pistols. Sunday Telegraph, p. 1.

Wallace, N. (2004, December 31). Chubb fined $\$ 1.5 \mathrm{~m}$ over phantom security patrols. Sydney Morning Herald, p. 6.

Wallace, N. (2006, August 5). I'm glad it's over: Robber's killer freed. The Sydney Morning Herald, p. 3.

Wheeler, J. (2005). An independent review of airport security and policing for the Government of Australia. Canberra: Australian Government Airport Security and Policing Review. 